40. Minuto F, Barreca A, Ferrini S, Mazzochi G, Del Monte P, Giordano G 1982 Growth hormone secretion in pubertal and adult subjects. Acta Endocrinol 99:161-165

41. Zadik Z, Chalew SA, McCarter J Jr, Mesitas M, Kowarski AA 1985 The influence of age on the $24 \mathrm{hr}$ integrated concentration of growth hormone. $\mathrm{J}$ Clin Endocrinol Metab 60:513-516

42. Argente J, Evain-Brion D, Munoz-Villa A, Garnier P, Hernandez M, Donna- dieu M 1986 Relationship of plasma growth hormone releasing hormone levels to pubertal changes. J Clin Endocrinol Metab 63:680-682

43. Gelato MC, Malozowski S, Caruso-Nicoletti M, Levine Ross J, Pecovitz OH, Rose S, Loriaux DL, Cassora F, Merriam GR 1986 Growth hormone (GH) responses to $\mathrm{GH}$-releasing hormone during pubertal development in norma boys and girls: comparison to idiopathic short stature and GH deficiency. J Clin Endocrinol Metab 63:174-179

\title{
Announcements
}

\section{Abstract Deadline}

The American Pediatric Society and The Society for Pediatric Research announce the abstract deadline for the 1990 Annual Meeting (May 7-11, 1990, Anaheim Hilton \& Convention Center, Anaheim, CA) has been set as January 4, 1990.

For further information contact: 2650 Yale Blvd., S.E., Suite 104, Albuquerque, NM 87106 (505) 764-9099.

\section{Joint PhD-Fellowship Training Program}

The University of Chicago Department of Pediatrics announces its unique, new Pediatric Science Training/ $\mathrm{PhD}$ Program. Trainees wishing to pursue an academic career may simultaneously pursue subspecialty training and a graduate school program leading to the $\mathrm{PhD}$ degree in this 5-year program. Training is available in most pediatric subspecialties, and research opportunities are available in diverse fields, including the social and behavioral sciences as well as the biological sciences. Applications are being accepted for 1990 and 1991. This program is funded by the National Institutes of Child Health and Human Development. Address inquiries to Robert L. Rosenfield, MD, Program Director, Pediatric Science Training/PhD Program, Wyler Children's Hospital, 5841 South Maryland, Chicago, IL 60637.

\section{7th Annual Seminar in Pediatric Nephrology}

The 17th Annual Seminar in Pediatric Nephrology, "Current Concepts in Diagnosis and Management," will be held at the Diplomat Hotel and Country Club, Hollywood, FL, February 5-10, 1990. For more information contact Pearl Seidler, Division Coordinator, Department of Pediatrics, Division of Pediatric Nephrology, University of Miami School of Medicine, P.O. Box 016960, Miami, FL 33101, (305) 549-6726.

\section{Update on Diabetes in Childhood}

The International Study Group on Diabetes in Children and Adolescents (ISGD) announces a course on "Update on Diabetes in Childhood," March 17-24, 1990, in Malga, Ciapela, Marmolada, Italy. The course is addressed to pediatricians, practitioners, and endocrinologists dealing with children and adolescents. Directors of the course of Dr. L. Pinelli, University of Verona, Italy, and Prof. Z. Laron, Tel Aviv University, Israel. The scientific program will be held in the mornings and evenings, and during the day winter sports can be enjoyed in the Alps. For further information contact Dr. L. Pinelli, Servizio di Diabetologia Pediatrica, Policlinico, I-37134, Verona, Italy; Telephone 0039-45-933667; FAX 0039-45-508222.

\section{Hyperlipidemia in Childhood and the Development of Atherosclerosis}

A conference on Hyperlipidemia in Childhood and the Development of Atherosclerosis will be held May 2-4, 1990, at the Hyatt Regency, Bethesda, MD. This conference will examine the role of hyperlipidemia and dyslipidemia in childhood in relation to the development of atherosclerosis. The program will focus initially on morphologic development of the atherosclerotic plaque, pathologic findings in pediatric autopsy series, biochemical correlates, and cellular models of atherosclerosis in the young. Distribution of plasma cholesterol and lipoprotein levels in children will be reviewed, including genetic, dietary, developmental, lifestyle, and pharmacologic influences on serum levels. Tracking of lipid levels over time will be reviewed, as well as international comparisons of lipids in pediatric populations. Cholesterol screening of children will be presented both from high-risk and population-based viewpoints. Pediatric office-based, school-based, and community-wide cholesterol screening activities and interventions will be described. Dietary and pharmacologic therapy of lipid disorders in children will be presented. Abstract deadline is December 11, 1989. The abstract, including title, author(s), and affiliation must be typed single space within a $5 \times 4-3 / 8$ inch rectangle, and sent to Dr. Christine L. Williams, Preventive Cardiology Center, New York Medical College, Valhalla, New York 10595. For further information, contact Conference Department, The New York Academy of Sciences, 2 East 63rd Street, New York, NY 10021, (212) 838-0230. 